\title{
Impact of extreme events on pollinator assemblages
}

\author{
Hilary E Erenler; Michael PGillman; and Jeff Ollerton
}

Insect pollinators face a number of well-documented threats that challenge their survival at an individual and community level. The effect of extreme events on pollinator assemblages has received little attention to date, partly due to a lack of consensus on what constitutes extreme, but also because robust pre-event data is often lacking. Here, the term SHOCK (Sudden, High-magnitude Opportunity for a Catastrophic 'Kick') is used to encompass attributes of extreme events that carry the potential to add additional challenges to insect communities already facing environmental stressors. Selected events from two SHOCK categories are explored (those with natural origins and those that are human-mediated). The value of studying single events is considered in the context of a third category; humanenhanced SHOCKs.

\section{Introduction}

Diverse insect pollinator communities, including wild and managed bees (Hymenoptera), butterflies and moths (Lepidoptera), flies (Diptera) and beetles (Coleoptera), provide mutually beneficial ecosystem functions for natural and agricultural systems [1-3]. Declines in insect pollinator species richness and abundance are well documented and linked to habitat loss, agricultural intensification and the spread of non-native species and pathogens, all of which may be exacerbated by anthropogenic climate change $[4,5,6 \bullet]$.

The impact of extreme events on pollinator communities has received less attention, partly due to a lack of consensus on what constitutes an extreme event [7•], but more commonly because of a paucity of robust pre event data against which to measure short and long- term pollinator responses. Despite their sporadic nature, single high-impact events have the potential to temporarily or permanently disrupt mutualistic insect-plant interactions $[8,9]$; causing alterations to the availability of pollinator foraging and nesting resources $[10,11]$ and leading to changes in pollinator community composition, including an increase in generalist species $[12,13]$.

This synthesis identifies known responses of pollinator assemblages to a selection of natural and directly human-mediated extreme events. Separately, in accepting that humanenhanced extreme events, that is, natural events exacerbated by human actions, are likely to increase in frequency, we consider the importance of pre-event data gathering and the usefulness of studying single events.

\section{What is an extreme event?}

Extreme events comprise some combination of low frequency, high unpredictability and high magnitude. They exist as outliers against a backdrop of observed variation in occurrence and severity of different processes and states. The terms 'perturbation' [14] and 'abruptness' [15] have both been used to describe deviations from continuous background processes. In acknowledging the difficulties of setting parameters (and collecting data) against which to benchmark extreme events as anthropo- genic activities alter natural processes at an increasingly rapid pace [16-18], we have deliberately avoided fixed definitions of what constitutes 'extreme' in the context of frequency, predictability, magnitude and geographical reach. Instead, we use the term SHOCK (Sudden, High-magnitude Opportunity for a Catastrophic 'Kick') to encompass attributes of extreme events that have the potential to adversely affect pollinator communities (Figure 1). 


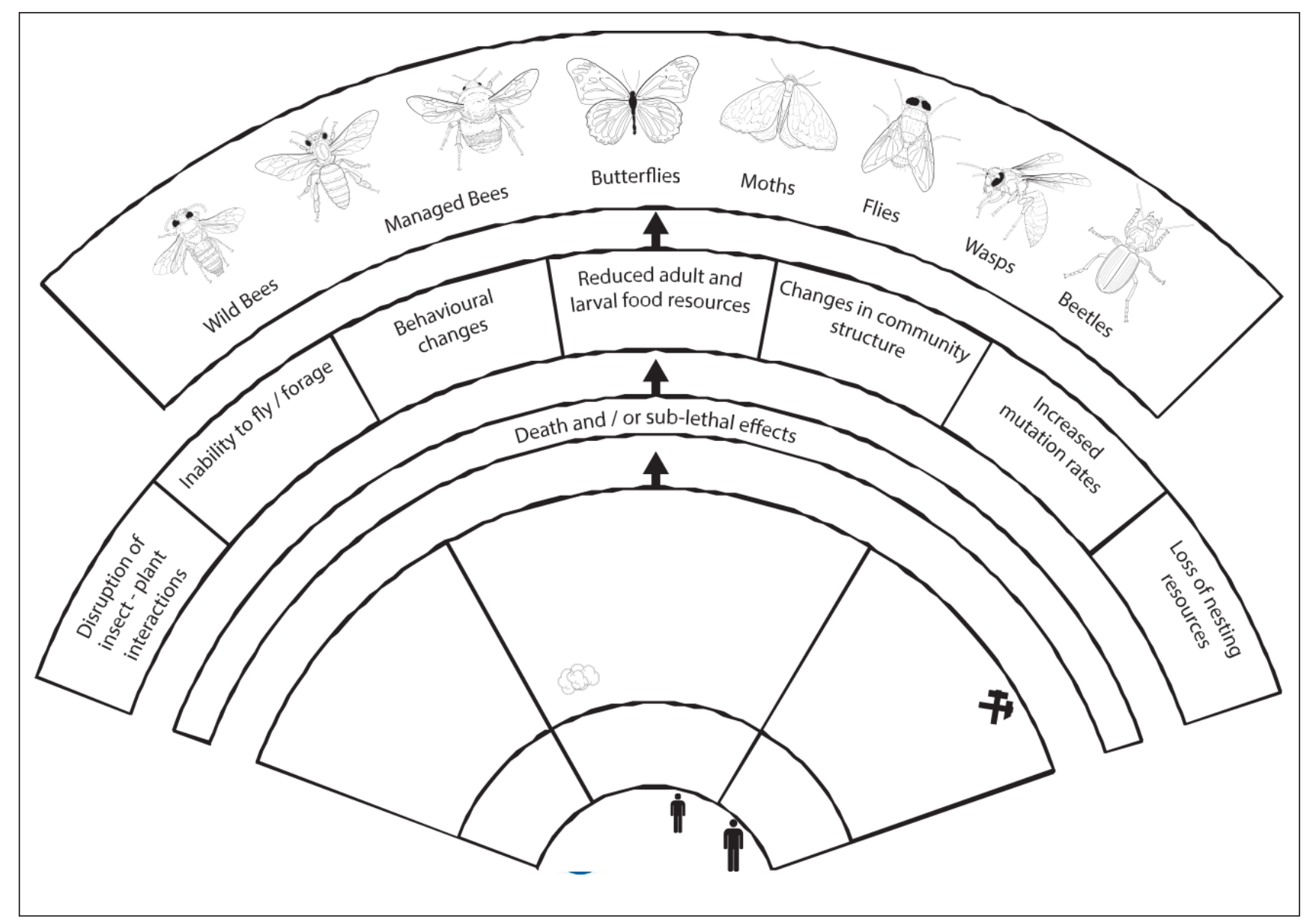

Figure 1 - A selection of natural SHOCKs, human-enhanced natural SHOCKs and directly human-mediated SHOCKs which have the potential to affect pollinator assemblages in various ways. Some of these are direct, immediate and lethal, such as loss of nest sites and future generations in diapause as a result of inundation, for example, flooding or dam collapse at mining sites. Others are sublethal but limit flight and the ability to forage, for example, the result of exposure to, or ingestion of, atmospheric volcanic ash particles. Finally, there are longerterm effects, expressed as deleterious genetic mutations resulting from exposure to increased levels of radiation following nuclear accidents.

\section{Natural SHOCKs}

Volcanic eruptions

Erupting volcanoes can lead to multiple lethal and sub- lethal SHOCKs for insect communities [19]. Ash, gas and lahars reduce or eliminate flowering resources used for food or brood nutrition [20]. Insect exoskeletons are vulnerable to physical damage caused by the abrasive nature of ash, leading to rapid desiccation, whilst the ingestion of ash contaminated pollen and nectar causes internal chemical and physical damage [21]. Ground nesting bees may suffer complete loss of nest sites or be reproductively compromised following exposure to ash and gas [22]. Other consequences include damage to wing structures which alters foraging patterns and causes loss of flight [23], as well as an increase in aggressive behaviour [24 and references within].

Not all outcomes are negative, however. Following a substantial Chilean ash fall event, declines in an invasive social wasp species were noted [25], which favoured the recovery of native wasp communities. This suggests that whilst disturbance may aid initial invasion processes, SHOCKs may facilitate the re-occupation of vacated niches by native communities [20]. 
Despite the potentially devastating losses of flora resulting from volcanic episodes, butterflies and other generalist pollinators, as well as specialist fig wasps and their fig tree hosts, may be able to rapidly re-colonise an area [26- 28]. Indeed, in spite of their highly specialised pollination systems, it seems figs have a remarkable ability to quickly reestablish their relationships with pollinators following an extreme event $[29,30]$.

In the case of repeated volcanic SHOCKs, network studies have established that mutualistic plant-pollinator communities may exhibit resilience to these episodic events, thereby aiding post-SHOCK recovery [31•].

\section{Alterations in solar flux}

Suboptimal flying conditions occur when there are alterations in solar flux. This can follow an increase in atmospheric dust concentrations after a volcanic explosion [32], but also occur during solar eclipses [33••]. Solar eclipses therefore represent SHOCKs that have the potential to alter pollinator behaviour through curtailment of flight. Whilst the temporary, but significant, temperature drop associated with a 90-minute solar eclipse in 2017 was not found to be a driver in reduced flight [33.•], possibly due to the broad thermal tolerances exhibited by many bee species [34], alterations in solar flux resulted in flights ceasing altogether during the complete darkness phase of the eclipse [33・•]. The implications are that natural SHOCKs can limit or halt flight, leading to a reduction in foraging for individual or brood nutrition, and that this has a consequence for insect- pollinated plants.

\section{Human-mediated SHOCKs}

Nuclear incidents

Enhanced radiation levels produce elevated rates of genetic damage and increased mutation rates in a range or organisms, leading to physiological, developmental, morphological and behavioural changes $[35,36]$. Human-mediated releases of radionuclides via Level 7 nuclear incidents have occurred only twice to date; the Chernobyl Nuclear Power Plant (NPP) disaster of 1986 and the Fukushima Dai-ichi NPP accident in 2011. In the highly radioactive area of the Chernobyl Exclusion Zone 25 years after the event, bumblebees and butterflies were both found to exhibit significant declines in abundance with increasing levels of radiation. How- ever, in Fukushima, six months after the event, whilst the abundance of butterflies was negatively affected along gradients of radiation, bumblebees did not exhibit a similar response [37]. This suggests that in the immediate aftermath of a nuclear incident, radiotoxicity is the big- gest SHOCK, whilst over longer time-frames a mixture of radiotoxicity and mutation-accumulation effects com- bine, which results in pollinator taxa responding in different ways $[37,38]$. Haplodiploidy, associated with pollinating bees and wasps (Hymenoptera), is believed to facilitate the rapid elimination of lethal and deleterious genes [39]. This process may be important in the wake of a nuclear incident.

In laboratory conditions, increasingly severe abnormalities in successive generations of the pale grass blue butterfly, Zizeeriamaha, exposed externally (as larvae and pupae) and internally (via ingested food) to Fukushima nuclear contaminants have been observed [40]. This suggests that the strong trans-generational legacy effects of exposure to human released radionuclides are likely to impose an, as-yet, potentially underappreciated burden on populations in the wild [41・•].

Running contrary to the reported negative effects of nuclear disasters is the potential upside associated with humans being absent from an area, as shown by studies of mammals in the Chernobyl Exclusion Zone [42]. These benefits could include habitat regeneration following the abandonment of intensive agriculture, which is a known driver of pollinator loss [4].

\section{Mining and industrial accidents}


Unusually high levels of heavy metal contaminants occur in the environment as a result of mining and industrial activities [43,44]. These contaminants enter pollinator biological cycles via plant resources including plant tis- sue, pollen and nectar [45,46•], and, in the case of several insect groups, including bees and butterflies, can lead to mortality, developmental abnormalities and an alteration in female reproductive success [47-49]. Mining and industrial accidents represent human-mediated SHOCKs through the sudden release of large quantities of contaminants into the environment, often over short periods. The collapse of the Funda o dam in Brazil, built to hold back iron ore tailings from mining activities, unleashed 43 million $\mathrm{m} 3$ of mining waste into the environment on a single day in 2015 , and is considered the world's worst mining dam disaster [50]. The outcome for pollinator assemblages after this, and other industrial accidents, remains largely unknown [6•,51]. Studies have shown that some insects may unwittingly expose themselves to lethal doses of contaminants. For example, honey bees are unable to discern that a lethal dose of selenium is present in a sucrose solution and readily consume it [52]. Whilst some taxa, including bumblebee, ant and beetle species, have been shown to exhibit resilience under different gradients of heavy metal pollution (by means of accumulation, concentrationregulation and subsequent excretion [53,54•]), the effects on pollinators of a cocktail of pollutants, including the flocculants and coagulants present in mining tailings, is currently undocumented [51].

\section{Human-enhanced SHOCKs}

In addition to natural and human-mediated SHOCKs, a third category (human-enhanced SHOCKs) exists. This represents natural events whose frequency and/or magnitude have been altered through human actions. Prime examples of this are extreme climatic events (ECEs) such as: hurricanes, cyclones and typhoons; prolonged or extreme drought or flooding; increased frequency or severity of wild fires, and extremely high or low temperatures. It is hypothesised that an increase in the frequency of these human-mediated SHOCKs will pose additional challenges to pollinator communities already compromised due to environmental stressors [55•]. A systematic review across four categories of natural hazard (including examples from our natural and human-enhanced SHOCKs) emphasises the need for greater understanding of the effects on pollination for both conservation and agriculture [56••].

Examining specific climate change effects on pollinator assemblages, and the myriad of approaches and challenges involved with measuring these, is beyond the scope of this paper, and has been covered elsewhere $[5,6 \bullet, 7 \cdot, 57,58]$. However, some of the detailed considerations regarding species and ecosystem responses to ECEs have wider application to non-climate-related extreme events (SHOCKs), and to pollinators in particu- lar. Determination of the (nonlinear) biological response function to ECEs and its underlying mechanisms [7•] is certainly desirable for natural and human-mediated SHOCKs. Likewise, the use of spatial and temporal observational data is not necessarily appropriate (or available), for all SHOCKs (unlike most ECEs), but the use of experimental manipulations and models may prove to be beneficial $[7 \cdot, 59 \cdot \bullet]$.

An important emerging theme is the value to be gained from studying single events particularly, but not exclusively, when they punctuate a long-term study [59・•]. Despite potential criticism that the results from these events fail to meet statistical norms for replication and lack availability of controls against which to measure responses, they help meet the current 'call to arms' to better understand how pollinators might fare in the future as the frequency of extreme climatic events increases [60,61•]. Even in the absence of longterm, pre-event data, studying the outcomes of a single SHOCK, regard- less of its cause, can provide valuable insights into the biological responses of pollinators $[41 \bullet \bullet, 62 \cdot]$.

\section{Concluding remarks}


SHOCKs take many forms and vary in their origin and the responses they elicit. Natural and human-mediated SHOCKs can collide to generate unpredictable human- enhanced events. This means pollinator communities that are already facing environmental stressors may be more frequently exposed to events that can alter community composition and even their existence.

Volcanic eruptions of varying severity occur regularly around the globe; however, supervolcanic eruptions, and their potential effects on biological communities, including pollinators, remain the subject of speculation [63]. The recent work on pollinator responses to solar eclipses [33.•] provides a useful insight into how altered light levels from volcanic dust might affect pollinators' ability to forage following larger or global-level volcanic events.

Nuclear incidents remain rare, but increased demand for non-fossil-fuel energy means the ageing infrastructure of some existing nuclear power plants can combine with an unfortunate sequence of events (such as an earthquake then a tsunami), resulting in immediate and severe local and regional effects on pollinators. The transgenerational effects of such SHOCKs on pollinator populations in the wild are only now being appreciated. Similarly, previously unimagined extreme events, such as the infrastructure failure of a dam holding back mining tailings, can become SHOCKs that destroy habitats, and initiate a cascade of catastrophic consequences for pollinator assemblages.

Depending on the ecological and behavioural traits of pollinator communities, food resource availability can become significantly compromised following a SHOCK, resulting in reductions to the quantity or quality of adult and larval food resources including flowers and prey for carnivorous species. Separately, bees and wasps may be affected to a greater or lesser extent by SHOCKs such as volcanic events, inundation following mining disasters or nuclear incidents depending on whether they are aerial or ground nesting species.

Reports of outcomes from single-event studies can pro- vide valuable insights into how pollinators respond both in the immediate aftermath of SHOCKs and through subsequent generations. Moreover, they offer the opportunity to contribute to a wider base of knowledge against which practical responses can be evaluated and a theoretical framework built.

\section{REFERENCES}

Potts SG, Biesmeijer JC, Kremen C, Neumann P, Schweiger O,Kunin WE: Global pollinator declines: trends, impacts and drivers. Trends Ecol Evol 2010, 25:345-353 http://dx.doi.org/ 10.1016/j.tree.2010.01.007.

Klein A-M, Vaissiere BE, Cane JH, Steffan-Dewenter I, Cunningham SA, Kremen C, Tscharntke T: Importance of pollinators in changing landscapes for world crops. Proc R Soc Lond B Biol Sci 2007, 274:303-313 http://dx.doi.org/10.1098/rspb.2006.3721.

Ollerton J: Pollinator diversity: distribution, ecological function, and conservation. Annu Rev Ecol Evol Syst 2017, 48:353-376 http://dx.doi.org/10.1146/annurev-ecolsys-110316-022919.

Ollerton J, Erenler H, Edwards M, Crockett R: Pollinator declines. Extinctions of aculeate pollinators in Britain and the role of large-scale agricultural changes. Science 2014, 346:1360-1362 http://dx.doi.org/10.1126/science.1257259.

Settele J, Bishop J, Potts SG: Climate change impacts on pollination. Nat Plants 2016, 2:16092 http://dx.doi.org/10.1038/nplants.2016.92.

Sa' nchez-Bayo F, Wyckhuys KAG: Worldwide decline of the 
entomofauna: A review of its drivers. Biol Conserv 2019, 232:8-27. A meta-analysis of declining insect species across the globe highlights key contributors, including habitat loss/conversion and pollution.

van de Pol M, Jenouvrier S, Cornelissen JHC, Visser ME: Behavioural, ecological and evolutionary responses to extreme climatic events: challenges and directions. Philos Trans R Soc B 2017, 372 http://dx.doi.org/10.1098/rstb.2016.0134.

Discusses the importance of the biological response function for understanding and predicting responses to extreme climatic events.

Impact of extreme events on pollinator assemblages Erenler, Gillman and Ollerton 37 www.sciencedirect.com Current Opinion in Insect Science 2020, 38:34-396063

Landry C: Changes in pollinator assemblages following hurricanes affect the mating system of Laguncularia racemosa (Combretaceae) in Florida, USA. J Trop Ecol 2013, 29:209-216 http://dx.doi.org/10.1017/S0266467413000266.

Hoiss B, Krauss J, Steffan-Dewenter I: Interactive effects of elevation, species richness and extreme climatic events on plant-pollinator networks. Glob Change Biol 2015, 21:40864097 http://dx.doi.org/10.1111/gcb.12968.

Phillips BB, Shaw RF, Holland MJ: Drought reduces floral resources for pollinators. Glob Change Biol 2018, 24:3226-3235.

Aranda R, Aoki C: Diversity and effect of historical inundation on bee and wasp (Hymenoptera: Apoidea, Vespoidea) communities in the Brazilian Pantanal. J Insect Conserv 2018, 22:581-591 http://dx.doi.org/10.1007/s10841-018-0087-3.

Minckley RL, Roulston TH, Williams NM: Resource assurance predicts specialist and generalist bee activity in drought. Proc R Soc Lond B Biol Sci 2013, 280:20122703 http://dx.doi.org/10.1098/rspb.2012.2703.

Biella P, Akter A, Ollerton J, Tarrant S, Jane9cek S, Jersa' kova' J, Klecka J: Experimental loss of generalist plants reveals alterations in plant-pollinator interactions and a constrained flexibility of foraging. Sci Rep 2019, 9:7376 http://dx.doi.org/10.1038/s41598-019-43553-4.

Pickett STA, White PS (Eds): The Ecology of Natural Disturbance and Patch Dynamics. Academic Press; 1985.

White PS, Jentsch A: The search for generality in studies of disturbance and ecosystem dynamics. In Progress in Botany. Edited by Esser K, Lu"ttge U, Kadereit JW, Beyschlag W. Springer; 2001 http://dx.doi.org/10.1007/978-3-642-56849-7 17.

Carter JM, Orive ME, Gerhart LM, Stern JH, Marchin RM, Nagel J, Ward JK: Warmest extreme year in U.S. history alters thermal requirements for tree phenology. Oecologia 2017, 183:1197-1210 http://dx.doi.org/10.1007/s00442-017-3838-z.

Jentsch A, Kreyling J, Beierkuhnlein C: A new generation of climate-change experiments: events, not trends. Front Ecol Environ 2007, 5:365-374 http://dx.doi.org/10.1890/1540-9295 (2007)5[365:ANGOCE]2.0.CO;2.

Kent EC, Kennedy JJ, Smith TM, Hirahara S, Huang B, Kaplan A, Parker DE, Atkinson CP, Berry DI, Carella G et al.: A call for new approaches to quantifying biases in observations of sea surface temperature. Bull Am Meteorol Soc 2019, 98:1601-1616 
Morales CL, Saez A, Arbetman MP, Cavallero L, Aizen MA:Detrimental effects of volcanic ash deposition on bee fauna and plant-pollinator interactions. Ecología Austral 2014, 24:4250 .

Brattstrom BH: Ba' rcena Volcano, 1952: a 60-year report on the repopulation of San Benedicto Island, Mexico, with a review of the ecological impacts of disastrous events. Pacific Conserv Biol 2015, 21:38-59 http://dx.doi.org/10.1071/PC14903.

Wille A, Fuentes G: Efecto de la ceniza del Volca' n Irazu' (Costa Rica) en algunos insectos. Revista de Biologia Tropical 1975, 23:165-175.

Erenler HE, Orr MC, Gillman MP, Parkes BRB, Rymer H, Maes J-M: Persistent nesting by Anthophora Latreille, 1803 (Hymenoptera: Apidae) bees in ash adjacent to an active volcano. Pan-Pac Entomol 2016, 92:67-78 http://dx.doi.org/10.3956/2016-92.2.67.

Martínez AS, Masciocchi M, Villacide JM, Huerta G, Daneri L, Bruchhausen A, Rozas G, Corley JC: Ashes in the air: the effects of volcanic ash emissions on plant-pollinator relationships and possible consequences for apiculture. Apidologie 2013, 44:268-277 http://dx.doi.org/10.1007/s13592-012-0177-2.

Elizade L: Volcanism and arthropods: a review. Ecologi'a Austral 2014, 24:3-16.

Masciocchi M, Pereira AJ, Lantschner MV, Corley JC: Of volcanoes and insects: the impact of the Puyehue-Cordon Caulle ash fall on populations of invasive social wasps, Vespula spp. Ecol Res 2013, 28:199-205 http://dx.doi.org/10.1007/s11284-012-1004-y.

Compton SG, Thornton IWB, New TR, Underhill I: The colonization of the Krakatau islands by fig wasps and other chalcids (Hymenoptera, Chalcidoidea). Philos Trans R Soc Ser B 1988, 322:459-470 http://dx.doi.org/10.1098/rstb.1988.0138.

New TR, Thornton IWB: The butterflies of Anak Krakatau, Indonesia: faunal development in early succession. J Lepidopterists Soc 1992, 46:83-86.

Thornton IWB: Krakatau. The Destruction and Reassembly of an Island Ecosystem. Harvard University Press; 1996.

Shanahan M, Harrison RD, Yamuna R, Boen W, Thornton IWB: Colonization of an island volcano, Long Island, Papua New Guinea, and an emergent island, Motmot, in its caldera lake. V. Colonization by figs (Ficus spp.), their dispersers and pollinators. J Biogeogr 2003, 28:1365-1377 http://dx.doi.org/10.1046/j.13652699.2001.2811121365.x.

Chiu YT, Bain A, Deng SL, Ho YC, Chen WH, Tzeng HY: Effects of climate change on a mutualistic coastal species: recovery from typhoon damages and risks of population erosion. PLoS One 2017, 12:e0186763 http://dx.doi.org/10.1371/journal.pone.0186763.

Kishi S, Sakura N, Yoshikawa T, Hiraiwa MK, Katoh K: Interaction between insects and insect-pollinated plants on Miyake Island after a recent volcanic eruption: a comparison between vegetation types. J Asia-Pac Entomol 2017, 20:964-970 http://dxdoi.org/10.1016/j.aspen.2017.07.006.

Network structure of plants and flower visitors was similar amongst communities with different levels of volcanic damage, approximately ten years after a major eruption. 
Turco RP, Toon OB, Ackerman TP, Pollack JB, Sagan C: Nuclear winter: global consequences of multiple nuclear explosions. Science 1983, 23:1283-1292 http://dx.doi.org/10.1126/science.222.4630.1283.

Galen C, Miller Z, Lynn A, Axe M, Holden S, Storks L, Ramirez E, Asante E, Heise D, Kephart S, Kephart J: Pollination on the dark side: acoustic monitoring reveals impacts of a total solar eclipse on flight behavior and activity schedule of foraging bees. Ann Entomol Soc Am 2019, 112:20-26 http://dx.doi.org/10.1093/aesa/say035.

A citizen-science supported study revealed that changes in light intensity and not temperature reduced the buzz density of bees during a solar eclipse.

Hollis Woodard S: Bumble bee ecophysiology: integrating the changing environment and the organism. Curr Opin Insect Sci 2017, 22:101-108

http://dx.doi.org/10.1016/j.cois.2017.06.001.

Dantchenko A, Emmel TC, Sourakov A: Nuclear pollution and gynandromorphic butterflies in southern Russia. Holarctic Lepidoptera 1995, 2:77-79.

Mousseau TA, Møller AP: Genetic and ecological studies of animals in Chernobyl and Fukushima. J Hered 2014, 105:704-709 http://dx.doi.org/10.1093/jhered/esu040.

Møller AP, Nishiumi I, Suzuki H, Ueda K, Mousseau TA: Differences in effects of radiation on abundance of animals in Fukushima and Chernobyl. Ecol Indicators 2014, 24:75-81 http:// dx.doi.org/10.1016/j.ecolind.2012.06.001.

Møller AP, Mousseau TA: Reduced abundance of insects and spiders linked to radiation at Chernobyl 20 years after the accident. Biol Lett 2009, 5:356-359 http://dx.doi.org/10.1098/ rsbl.2008.0778.

White JD: Chromosomal mechanisms in animal reproduction. Ital J Zool 1984, 51:1-23 http://dx.doi.org/10.1080/11250008409439455.

Hiyama A, Nohara C, Kinjo S, Taira W, Gima S, Tanahara A, Otaki JM: The biological impacts of the Fukushima nuclear accident on the pale grass blue butterfly. Sci Rep 2012, 2:570 http://dx.doi.org/10.1038/srep00570.41.

Hancock H, Vo NTK, Omar-Nazir L, Batlle JVI, Otaki JM, Hiyama A, Byun SH, Seymour CB, Mothersill C: Transgenerational effects of historic radiation dose in pale grass blue butterflies around Ecology Current Opinion in Insect Science 2020, 38:34-39 www.sciencedirect.com

Fukushima following the Fukushima Dai-ichi Nuclear Power Plant meltdown accident. Environ Res 2019, 168:230-240 http://dx.doi.org/10.1016/j.envres.2018.09.039.

Investigations of the leak of radioactive isotopes from the Fukushima Daiichi nuclear power plant revealed transgenerational effects on butterflies.

Deryabina TG, Kuchmel SV, Nagorskaya LL, Hinton TG, Beasley JC, Lerebours A, Smith JT: Long-term census data reveal abundant wildlife populations at Chernobyl. Curr Biol 2015, 25:R824-R826 http://dx.doi.org/10.1016/j.cub.2015.08.017.

Nriagu JO: A history of global metal pollution. Science 1996, 272:223 http://dx.doi.org/10.1126/science.272.5259.223. 
Nriagu JO, Pacyna JM: Quantitative assessment of worldwide contamination of air, water and soils by trace metals. Nature 1988, 333:134-139 http://dx.doi.org/10.1038/333134a0.

Matin G, Kargar N, Buyukisik HB: Bio-monitoring of cadmium, lead, arsenic and mercury in industrial districts of Izmir, Turkey by using honey bees, propolis and pine tree leaves. Ecol Eng 2016, 90:331-335 http://dx.doi.org/10.1016/j.ecoleng.2016.01.035.46.

Nascimento NO, Nalini HA, Ataide F, Abreu AT, Antonini Y: Pollen storage by stingless bees as an environmental marker for metal contamination: spatial and temporal distribution of metal elements. Sociobiology 2018, 65:259-270

http://dx.doi.org/10.13102/sociobiology.v65i2.2078.

Analysis of the composition of pollen of stingless bees showed them to be effective bioindicators for a range of hazardous and other elements, including heavy metals.

Moroon D, Szentgyo "rgyi H, Sko' rka P, Potts SG, Woyciechowski M: Survival, reproduction and population growth of the bee pollinator, Osmia rufa (Hymenoptera: Megachilidae), along gradients of heavy metal pollution. Insect Conserv Divers 2014, 7:113-121

http://dx.doi.org/10.1111/icad.12040.

Nieminen M, Nuorteva P, Tulisalo E: The effect of metals on the mortality of Parnassius apollo larvae (Lepidoptera: Papilionidae). J Insect Conserv 2001, 5:1-7 http://dx.doi.org/ 10.1023/A:1011371119290.

Noret N, Josens G, Escarre' J, Lefe' bvre C, Panichelli S, Meerts P: Development of Issoria lathonia (Lepidoptera: Nymphalidae) on zinc-accumulating and nonaccumulating Viola species (Violaceae). Environ Toxicol Chem 2007, 26:565-571 http://dx.doi.org/10.1897/06413R.1.

Omachi CY, Siani SMO, Chagas FM, Mascagni ML, Cordeiro M, Garcia GD, Thompson CC, Siegle E, Thompson FL: Atlantic Forest loss caused by the world's largest tailing dam collapse (Fundã o Dam, Mariana, Brazil). Remote Sens Appl: Soc Environ 2018, 12:30-34 http://dx.doi.org/10.1016/j.rsase.2018.08.003.

Carmo FF, Kamino LHH, Tobias R Jr, Campos IC, Silvino G, Castro KJSX, Mauro ML, Rodrigues NUA, Miranda PS, Pinto CEF: Fundã o tailings dam failures: the environment tragedy of the largest technological disaster of Brazilian mining in global context. Perspect Ecol Conserv 2017, 15:145-151 http://dx.doi.org/10.1016/i.pecon.2017.06.002.

Burden CM, Elmore C, Hladun KR, Trumble JT, Smith BH: Acute exposure to selenium disrupts associative conditioning and long-term memory recall in honey bees (Apis mellifera). Ecotoxicol Environ Saf 2016, 127:71-79

http://dx.doi.org/10.1016/j.ecoenv.2015.12.034.

Szentgyo “rgyi H, Blinov A, Eremeeva N, Luzyanin S, Grze's I, Woyciechowski M: Bumblebees (Bombidae) along pollution gradient - heavy metal accumulation, species diversity, and Nosema bombi infection level. Polish J Ecol 2011, 59:599-610.

Mukhtorova D, Hlava J, Sza' kova' J, Kubı'k S, Vrabec V, Tlustos` P: Risk element accumulation in Coleoptera and Hymenoptera (Formicidae) living in an extremely contaminated area - a preliminary study. Environ Monit Assess 2019, 191:432 http://dx.doi.org/10.1007/s10661-019-7584-z.

Despite being in contact with extremely contaminated soil, some insects 
displayed limited uptake of pollution elements.

Klein S, Cabirol A, Devaud J-M, Barron AB, Lihoreau M: Why bees are so vulnerable to environmental stressors. Trends Ecol Evol 2017, 32:268-278 http://dx.doi.org/10.1016/j.tree.2016.12.009.

Central place foragers, such as social bees, are shown to be especially susceptible to environmental contaminants such as pesticides and heavy metals.

Nicholson CC, Egan PA: Natural hazard threats to pollinators and pollination. Glob Change Biol 2019, 1-12 http://dx.doi.org/10.1111/gcb.14840.

Systematic review of four natural hazard categories incorporating a meta-analysis on the effects of fire.

Byers DL: Studying plant-pollinator interactions in a changing climate: A review of approaches. Appl Plant Sci 2017, 5:1700012 http://dx.doi.org/10.3732/apps.1700012.

Forrest JR: Plant-pollinator interactions and phenological change: what can we learn about climate impacts from experiments and observations? Oikos 2015, 124:4-13

http://dx.doi.org/10.1111/oik.01386.

Altwegg R, Visser V, Bailey LD, Erni B: Learning from single extreme events. Philos Trans R Soc B 2017:372 http://dx.doi.org/10.1098/rstb.2016.0141.

Considers how to improve the effectiveness of single-event studies, with a focus on sampling and statistical methods.

Danforth BN, Minckley RL, Neff JL: The Solitary Bees. Princeton University Press; 2019.

Meiners JM, Griswold TL, Carril OM: Decades of native bee biodiversity surveys at Pinnacles National Park highlight the importance of monitoring natural areas over time. PLoS One 2019, 14:1-23 http://dx.doi.org/10.1371/journal.pone.0207566e0207566.

Highlights the importance of extensive and repeated samples to provide a baseline for assessment of the potential factors contributing to bee decline.

Galbraith SM, Cane JH, Moldenke AR, Rivers JW: Wild bee diversity increases with local fire severity in a fire-prone landscape. Ecosphere 2019, 10:e02668

http://dx.doi.org/10.1002/ecs2.2668.

Numbers of individuals and species of bee increased with fire severity in a naturally fireprone ecosystem.

Jones MT, Sparks RSJ, Valdes PJ: The climatic impact of super-volcanic ash blankets. Climate Dyn 2007, 29:553-564 http://dx.doi.org/10.1007/s00382-007-0248-7. 